\title{
Specialty training out-of-sync with job market
}

$\Lambda$ national forum should be convened to align postgraduate training with the realities of the job market, as flatlining demand for once highly sought-after specialties is leaving an increasing number of new graduates without work to match their skills or pay down their debts, Canadian Medical Association delegates say.

Delegates to the CMA's annual general meeting in St. John's, Newfoundland, adopted a resolution on Aug. 23 that will compel the association to promote a national alignment of training positions with "current and future societal needs, evolving models of care delivery and available health systems resources."

CMA should also assist physicians during all stages of their careers, with "special emphasis on helping medical students and residents make informed career choices by providing job-trend data and other career-planning resources," delegates said.

New graduates specializing in orthopedic surgery, cardiac surgery, neurosurgery and nephrology are among those unable to find jobs - although, ironically, the glut of specialists comes at time when Canada is struggling with physician shortages and long wait times for specialist care, Dr. Shirley Sze says.

The crux of the problem, Sze earlier told delegates, is poor human resource planning on the part of the provinces, and a lack of career planning information and resources provided to medical students before they start specialist training.

"There needs to be a national review of the specialty training spots and jobs that are available because residents match across Canada for their training positions, not just provincially," she explained.

About half of all resident physicians in Canada are concerned about finding employment, Dr. Roona Sinha told delegates. "As residents preparing to enter into practice, we want to be able to use all the skills and knowledge we have gained during our training to treat Canadian patients."

"It's not useful or fair for the system to train us if there are no positions for us in the end," she added.

As it stands, there are few sources of job-trend data readily available to medical students, and attempts in Ontario and British Columbia to provide work-

Other health human resources resolutions included ones that compel CMA to:

- examine the effect of increasing population longevity on sustainability of health human resources;

- examine practice location patterns of medical schools graduates to urban /rural distribution implications; and

- develop a toolkit to promote adoption of practice redesign techniques to enhance access to care.

Such health human resource issues have surfaced annually at CMA annual general meetings since the collapse of a major push for the creation of a comprehensive "pan-Canadian" strategy for educating, recruiting, licensing and equipping doctors that was recommended by a blue-ribbon panel called Task Force Two in 2006.

The comprehensive plan, $A$ Physician Human Resource

force information "is not coordinated," Sze says.

Students are required to make career choices earlier in their schooling than ever before, she adds. "Before, you would graduate from medical school, do a year of rotating internships and then decide. Now that decision is being made in second or third year."

With the average medical student facing some $\$ 158000$ in debt on graduation, many students gravitate to higher-earning specialties without a notion of the demand for such professionals, Sze says.

But Canada's aging population and the increasing incidence of chronic disease is driving a need for generalists. "There's changing medical practices and changing trends so you need to train the doctors that are able to cope with them," Sze explains. "If we don't inform our young people about these changes, and where the work is going to be, how can we possible meet future demands on the system?" for Canada: Final Report, urged wholesale reforms in five areas related to physician supply - education and training; interprofessionalism; recruitment and retention; licensure, regulatory issues and liability; and infrastructure and technology — while proposing that responsibility for overhauling the current system be vested with some manner of national agency (www.cmaj.ca/cgi/doi/10.1503 /cmaj.060598).

The proposal was eventually consigned to gather dust on library shelves after it became mired in quintessential Canadian squabbles over jurisdiction. Various medical associations argued that they shouldn't have to relinquish their licensing authority, while several provinces objected to a national approach to health human resources on the grounds that it would limit their ability to recruit doctors to underserviced areas. — Lauren Vogel, CMAJ 